\title{
Women's Managerial Level Involvement in Tourism Sector in Pokhara
}

\author{
Deepak Raj Paudel \\ Tek Bahadur Malla
}

\begin{abstract}
This study examines the factors that have effect on women's managerial level involvement in hospitality sector of tourism industry in Lakeside, Pokhara; a popular tourism area in Nepal using a census survey of 100 women. The schedule questionnaire and 10 key informants' interview (KII) were employed in order to collect primary data and to triangulate the results. Significance tests have been performed to determine the association between women's level of participation with all other possible variables using Chi-square test. Demographic factors such as age and marital status; socioeconomic factors like educational level, prior family involvement, condition of work enviournment, household headship, and social barriers have been identified as independent variables that might have effect on level of women's participation. The findings revealed that women's participation in managerial position is low (29\%) comparing to the operative level (71\%). All socioeconomic factors have significant influence on women's levels of participation.
\end{abstract}

Keywords: women's involvement, managerial position, tourism

\section{Introduction}

Tourism industry is a labor intensive service industry, which provides a lot of employment to the people of different levels and sectors. The tourism industry encompasses all activities by individuals, companies or organizations which supply, directly or indirectly, goods or services to tourist at their destination (Jackson, 1995). Tourism is a multifaceted industry that directly affects several sectors in the economy. It produces many jobs. As a result tourism jobs may not be any more cost effective than those in other sectors of the economy but the industry's ability to create employment still remains a major advantage to the community (Jackson, 1995). Tourism can violate women's rights, but it can also be used to challenge traditional roles and to empower women, in economic, social, cultural and political terms (Sijtsma, 2001). Daddi (2002) mentioned tourism's low skilled jobs were viewed as good opportunities for women and ethnic minorities. The Universal Declaration of Human Rights (1948) and the United Nations Convention on the Elimination of all Forms 
of Discrimination Against Women (CEDAW, 1979), and respective national legislation are the legal and policy basis of addressing human rights and women's rights issues in tourism (Keefe \& Wheat, 1998).

According to the book Economic impact of Tourism, "Tourism as a source of employment is particularly important for areas with no alternative sources of employment, as is often the case in non-industrial areas deficient is natural resources other than scenic attractions and climate" (Keefe and Wheat, 1998). According to a study conducted by the Wharton Econometric Forecasting Associates, travel and tourism is the largest industry in the world in terms of employment in almost every country of the world and travel and tourism employs more than 101 million people around the globe (Bhatia, 1994). Moreover, "proper cultivation of tourism is expected to contribute in foreign links of mutual understanding and appreciation for a better world of tomorrow" (Anand \& Bajracharya, 1985). According to Jackson (1995), management jobs are now attracting graduates of the new hospitality and tourism related degree/diploma courses, and also graduates with other kinds of expertise relevant to the industry, such as accounting, marketing or fluency in foreign language. This means that a number of different career paths can be followed by a person keen to enter the travel or hospitality industries.

Developers define the tourism industry as Nepal's comparative advantage in the global economy. It is widely believed that the employment opportunities generated by tourism industry is likely to be higher in developing countries than in developed countries (Shrestha, 2000). As an employment provider, the role of tourism sector in Nepal is more significant. "Tourism directly/indirectly employs an estimated 300,000 jobs in Nepal in 2000/01" (NTB, 2000). However, women's direct participation in employment in the tourism industry in Pokhara is observed very low 21.5\% (Tourism Office, 2005) as compared to men.. According to a survey conducted by Nepal Rastra Bank (1989), 8438 people were directly employed (7462 male and 976 female) in the tourism sector in the fiscal year 1986/87, including $70.1 \%$ in Hotels, followed by travel agencies $18.3 \%$ and trekking agencies $11.6 \%$. In the same way the indirect employment was 2852 (2618 male and 234 female), in the year 1986/87 (Shrestha, 2000). The tourism industry in Nepal took a quantum jump only after the establishment of air services in 1957. That means the promotion of tourism in the real sense started since 1960. At this stage some fine hotels such as Hotel Shanker (1964), Hotel de la Annapurna (1965), Hotel Soaltee (1966) and other international standard hotels within Kathmandu and Pokhara immersed in the developing process of hospitality industry in Nepal (Oli \& Chhetri, 2002). Like wise Pokhara also 
begun to develop as a central hub for trekking in the Annapurna region. Tourism in its early stage took its form in Pokhara region when the mule traders used to commute and pilgrims used to travel to Muktinath.

The foregoing review of literature suggests that women's level of participation can best be examined using demographic and socio-economic factors such as age, marital status and educational level, prior family involvement, work environment, household headship, and social barriers as the predictors. Hence, in this study, the demographic and socio-economic variables are used to identify the correlates of women's managerial level participation in tourism industry. This study has specifically been focused on the women who are directly involved in tourism industry especially in hotels at the Lakeside area, Pokhara. A number of studies have also discussed about the socio-cultural, economic and environmental aspects of tourism sector but none of such research works have focused towards the women's participation as managerial level. In this regard this study will be beneficial for the tourism industry related professionals, policymakers, planners, researchers, and concerned stakeholders. However, the study does not deal with the hotels that are not been the member of Regional Hotel Association of Nepal (RHAN), Pokhara chapter. The role of extraneous variables on the selected study variables is also assumed negligible.

\subsection{Objectives of the Study}

Tourism industry in this study incorporates companies or organizations which supply, directly, goods or services to tourists at their destination. In this study hotels are considered as the part of tourism industry sector. The objectives of the study are:

- To identify the different characteristics (namely demographic and socioeconomic) of women working in the tourism sector

- To assess the major factors that influence women's managerial level participation in tourism industry.

- To identify the levels of women's participation in tourism industry.

\subsection{Hypotheses}

- Demographic factors such as age and marital status is likely to affect the women's level of participation in tourism industry.

- Socioeconomic factors have impact on the level of women's participation in tourism industry. 


\section{Methodology}

\subsection{Study Site}

Pokhara, the tourism capital of western region situated 200 kilometers south-west of Kathmandu is a complete experience in itself where nature and cultural blend beautifully to present a spectacular panorama unparalleled anywhere else. It is also a popular tourist destination where many direct and indirect suppliers of goods and services to the incoming tourists are in existence with high probability of employment to both men and women. Lakeside, the main tourist area in the valley is situated at the east-west part of Pokhara and most of the tourism industry sectors including hotels, restaurants, travel and trekking agencies and so on are located here. Therefore, the area from Komagane Park gate to Camping Chok with approximately 300 meters right and left of its has been defined as the main study site where most of the tourism/businesses activities are concentrated.

\subsection{The Research Design}

The census survey research design was employed to meet the study objectives. Between September and November 2006, a census survey was conducted of all hotels in Lakeside, a central part of Pokhara Sub-metropolitan City, Nepal. 58 hotels have been identified through the RHAN Pokhara chapter. Each hotel was visited to determine eligibility of the respondents that is required for the study. Criteria included having female employees in the study area. Twelve hotels were not in operation in the area and six hotels did not have female employees. At the 40 eligible hotels, 20 hotels had female supervisors/ managers and 20 hotels had junior female employees only. There were all together 106 female employees among 40 eligible hotels. 6 females have their own family run hotel business. Hence they were excluded in the study, leaving only 100 cases in the study.

\subsection{Data Collection Procedures and Techniques}

The scheduled questionnaire was used in the census survey in order to collect the primary data. Each interview lasted for 20 to 30 minutes. The questions were chosen that were appropriate for employees working at hotels in Pokhara. The questionnaires were pre tested from 5 females employed outside the study area. Both closed and open ended questions with demographic and socioeconomic characteristics of the respondents were included in the questionnaire. All interviews were conducted by the second author. Besides these, 10 key informants' interview (KII's) (namely tourism entrepreneurs and experts) were also conducted in order to triangulate the results. 


\subsection{Data Processing and Analysis}

The data were checked for completeness and accuracy, and then coded for analysis. The SPSS version 11.5 was used to calculate percentage for all indicators. Significance tests have been carried out to determine the association between women's level of participation with other covariates using Chi-square test. Each independent variable such as: demographic and socioeconomic have been cross tabulated with women's level of participation. Multivariate analysis has not been carried out due to insufficiency in cases.

\section{Results and Discussions}

\subsection{Demographic Characteristics of the Respondents}

The main demographic factors as independent variables used in this study include age and marital status of the women. The age found vary from 18 years to 54 years (Table 1 ). Most of the women (38\%) were 20-24 aged, $26 \%$ were with age group of 25-29. Only $4 \%$ of women were under the higher age groups.

Table 1: Distribution of Respondents by Their Demographic Factors

\begin{tabular}{|c|c|c|c|c|}
\hline Variables & $\begin{array}{l}\text { Specifications } \\
\end{array}$ & Categories & Number & Percentage \\
\hline \multirow[t]{7}{*}{ Age } & \multirow{7}{*}{$\begin{array}{l}\text { Ordinal variable indicating the } \\
\text { age of the women }\end{array}$} & $\bullet 15-19$ & 5 & $5 \%$ \\
\hline & & • $20-24$ & 38 & $38 \%$ \\
\hline & & - $25-29$ & 26 & $26 \%$ \\
\hline & & - $30-34$ & 15 & $15 \%$ \\
\hline & & - $35-39$ & 5 & $5 \%$ \\
\hline & & - 40-44 & 7 & $7 \%$ \\
\hline & & $\cdot 45-54$ & 4 & $4 \%$ \\
\hline \multirow{3}{*}{$\begin{array}{c}\text { Marital } \\
\text { status }\end{array}$} & \multirow{3}{*}{$\begin{array}{l}\text { Dichotomous variable indicating } \\
\text { whether the women are married } \\
\text { or not. }\end{array}$} & - Unmarried & 21 & $21 \%$ \\
\hline & & - Married & 79 & $79 \%$ \\
\hline & & Total & 100 & $100 \%$ \\
\hline
\end{tabular}

It shows that as age increases, the participation of women in tourism industry becomes lower. Similarly, the women under the lowest age group 15-19 have also very low participation (5\%). It indicates that tourism sectors prefer women with maturity for employment. This revealed that both lower and higher age is not appropriate for the tourism employment. However, the lower age is found much preferable comparing to the higher one. With regard to the marital status, $79 \%$ of women were married. Generally it is seen that tourism industry prefers to employ unmarried women since an unmarried woman can give time for different working shifts compared to married one. However, this study 
showed the contrast findings. It is because out of 38 women 21 have got married during the age group 20-24. Likewise, under the age group 25-29 all 26 women were married. Hence as the age increases the married women's proportion becomes higher.

\subsection{Socio Economic Factors of the Respondents}

The socioeconomic factors included in this study are: education level, prior family involvement, work environment, household headship, and a common social concept about women's involvement in tourism industry as a barrier. With regard to the education level, it is found that most of the women (52\%) involved in the tourism industry have only primary level. Similarly, 16\% had middle level, 13\% had high school level, and 19\% had above high school level education (Table 2). As most of the tourism industry sectors in Pokhara area are running as a family business where hotels are not the exception in this regard. Not only women with the primary level of education but higher than that level too, it is found that most of them were working in the lower level positions. It is because of the lower level of education that they have.

It is commonly believed that women's involvement outside employment is highly influenced by their family member/s prior involvement in a specific sector. The positive influence of a family member's prior involved in a specific sector, and women's participation in the same sector is a common phenomenon. In the tourism industry too, it is found that if a family member is previously involved in this sector, women's involvement have found positively influenced. In this study, $41 \%$ of the respondents have found prior family involvement (Table 2). However, different factors such as: friend's help, family help, self innovation, and others help are seen vital in women's involvement in the tourism industry. The study showed that out of 41 women who have prior family involvement in the tourism sector, $19 \%$ were involved with the help of friend, $71 \%$ with the help of family, $5 \%$ with self innovation and 5\% with others help. About the women without prior family involvement in the tourism sector, out of 59 women $61 \%$ were involved with the help of friend, $19 \%$ with the help of family, $17 \%$ with the self innovation, and $3 \%$ with others help. The study findings showed the positive correlation between prior family involvements and women's participation in the tourism industry.

Work environment may have both aspects either favorable or unfavorable. Unfavorable work environment may ultimately lead an employee to quit the job. In this study, only $1 \%$ has responded that she is unsatisfied with her work environment. Remaining all had responded that they have favorable work environment. If $99 \%$ employees are satisfied 
with their work environment it indicates that they have favorable work environment in terms of the both physical and mental aspects. As being a service industry, tourism industry always provides a favorable work environment to its employees. The similar situation has been found in Nepalese context too. This study also tries to reveal the satisfaction level from the work environment. $81 \%$ respondents responded the medium level of satisfaction, $12 \%$ responded the high level of satisfaction and only $7 \%$ responded the low level of satisfaction from their work environment (Table 2).

Household head is a decision maker for every decision to be made in the favor of a male or female household member. Nepalese society is dominant with the male household headship and most of the decisions are being made by the male. If a female wants to involve herself in an outside work, she needs to get the permission from the household head. So, household head's decision plays a vital role in women's participation in outside job. In this study, 92\% respondents have found male household headship and only $8 \%$ have found female household headship which can be seen as a general trend in Nepalese context. However, out of the 92 respondents whose household head is male, only one has responded that she has no family support. The study showed that female household headship was more supportive to women comparing to male household headship.

Being a social creature, human being always need social support in every aspects of their life. Without social support no one can be progressive. In another word, social support is just like other basic needs for human beings' welfare and prosperity. It is generally seen that if society does not support any activity that someone wants to perform, he or she may not be able to go ahead with that wanted activity any more. In this context, in many aspects of life especially women are being victim of social restrictions and barriers. They are not always been allowed to involve outside employment and activities. There are always no direct social restrictions for women but our social structure has provided more roles to women that have to be performed at home. Not only this, in many aspects we can see the negative social concept about women's involvement in outside activities and job too. Such social concepts and barriers are preventing women to involve in outside employment. Literature review also indicates the same. Tourism industry is not the exception in this regard. Women who want to involve in tourism sector are also not been able due to such social barriers. About the specific social barriers, $52 \%$ responded that women's participation is low because of negative social thought about hotel job, $18 \%$ responded that the reason is lack of awareness, $3 \%$ responded that there is no favorable work environment and the same percent responded that women do not have wish to work in tourism industry. So, the major 
social barrier in this study is seen the negative social thought that has been preventing women to participate in the tourism industry.

The dependent variable in this study is the level of women's participation in tourism industry. It is hypothesized that this dependent variable depends on the seven independent variables chosen for the study which include: age, marital status, educational level, prior family involvement, work environment, household headship, and social barriers that have been preventing women to participate in the tourism industry. These seven independent variables are categorized under the demographic and socio-economic factors. Women's participation in the tourism industry can be observed from many different aspects and there may be lots more reasons of low participation of this group comparing to their counterpart men's participation. However, this study only analyzed the reasons and/or variables that have been chosen for the research. The result shows that more than seven in ten (71\%) of the women were participated as non managerial level whereas less than one third $(29 \%)$ were involved as managerial position.

Table 2: Number and Percentage of Respondents by Socioeconomic Factors.

\begin{tabular}{|c|c|c|c|c|}
\hline Variables & Specifications & Categories & Number & Percent \\
\hline \multirow{4}{*}{$\begin{array}{l}\text { Educational } \\
\text { level }\end{array}$} & \multirow{4}{*}{$\begin{array}{l}\text { Ordinal variable indicating } \\
\text { the educational attainment } \\
\text { level of the respondents }\end{array}$} & - Primary & 52 & $52 \%$ \\
\hline & & - Lower secondary & 16 & $16 \%$ \\
\hline & & - High school & 13 & $13 \%$ \\
\hline & & $\begin{array}{l}\text { - Above high } \\
\text { school }\end{array}$ & 19 & $19 \%$ \\
\hline \multirow{3}{*}{$\begin{array}{l}\text { Prior family } \\
\text { involvement }\end{array}$} & \multirow{3}{*}{$\begin{array}{l}\text { Nominal variable indicating } \\
\text { whether prior involvement } \\
\text { of the family member/s as } \\
\text { an employee and/or as an } \\
\text { entrepreneur in the tourism } \\
\text { industry. }\end{array}$} & - Involved & 41 & $41 \%$ \\
\hline & & - Not involved & 59 & $59 \%$ \\
\hline & & & & \\
\hline \multirow{4}{*}{$\begin{array}{l}\text { Involvement } \\
\text { support }\end{array}$} & \multirow{4}{*}{$\begin{array}{l}\text { Nominal variable indicating } \\
\text { from whom the respondent } \\
\text { get support for their } \\
\text { involvement in tourism } \\
\text { industry }\end{array}$} & - Friend's help & 44 & $44 \%$ \\
\hline & & - Family help & 40 & $40 \%$ \\
\hline & & - Self innovation & 12 & $12 \%$ \\
\hline & & - Others' help & 4 & $4 \%$ \\
\hline \multirow{3}{*}{$\begin{array}{l}\text { Work } \\
\text { enviournment } \\
\text { Condition }\end{array}$} & \multirow{3}{*}{$\begin{array}{l}\text { Nominal variable indicating } \\
\text { favorable or unfavourable } \\
\text { work condition that satisfies } \\
\text { the employee physically } \\
\text { and mentally. }\end{array}$} & - Favorable & 99 & $99 \%$ \\
\hline & & - Not favorable & 1 & $1 \%$ \\
\hline & & & & \\
\hline
\end{tabular}




\begin{tabular}{|c|c|c|c|c|}
\hline \multirow{3}{*}{$\begin{array}{l}\text { Satisfaction } \\
\text { form work } \\
\text { enviournment }\end{array}$} & \multirow{3}{*}{$\begin{array}{l}\text { Ordinal variable indicating } \\
\text { satisfaction level from work } \\
\text { enviournment in tourism } \\
\text { industry }\end{array}$} & • High & 12 & $12 \%$ \\
\hline & & - Medium & 81 & $81 \%$ \\
\hline & & - Low & 7 & $7 \%$ \\
\hline \multirow{2}{*}{$\begin{array}{l}\text { Household } \\
\text { headship }\end{array}$} & \multirow{2}{*}{$\begin{array}{l}\text { Nominal variable indicating } \\
\text { the whether the household } \\
\text { head is male or female of } \\
\text { the respondents }\end{array}$} & - Male & 92 & $92 \%$ \\
\hline & & - Female & 8 & $8 \%$ \\
\hline \multirow{3}{*}{$\begin{array}{l}\text { Support of } \\
\text { household } \\
\text { head }\end{array}$} & \multirow{3}{*}{$\begin{array}{l}\text { Nominal variable } \\
\text { indicating whether the } \\
\text { respondents get support } \\
\text { from the household head }\end{array}$} & - No response & 5 & $5 \%$ \\
\hline & & - Positive & 93 & $93 \%$ \\
\hline & & - Negative & 2 & $2 \%$ \\
\hline \multirow{8}{*}{$\begin{array}{l}\text { Social } \\
\text { barriers }\end{array}$} & \multirow{8}{*}{$\begin{array}{l}\text { Nominal variable indicating } \\
\text { the general social concept } \\
\text { about women's involvement } \\
\text { in the tourism industry } \\
\text { that prevents women to } \\
\text { participate in the tourism } \\
\text { industry. }\end{array}$} & - No response & 4 & $4 \%$ \\
\hline & & $\begin{array}{l}\text { - Negative social } \\
\text { thought }\end{array}$ & 52 & $52 \%$ \\
\hline & & - Lack of Wish & 3 & $3 \%$ \\
\hline & & $\begin{array}{l}\text { - Negative male } \\
\text { attitude }\end{array}$ & 4 & $4 \%$ \\
\hline & & $\begin{array}{l}\text { - No favorable } \\
\text { environment }\end{array}$ & 3 & $3 \%$ \\
\hline & & $\begin{array}{l}\text { - Home } \\
\text { involvement }\end{array}$ & 7 & $7 \%$ \\
\hline & & $\begin{array}{l}\text { - Lack of } \\
\text { awareness }\end{array}$ & 18 & $18 \%$ \\
\hline & & $\begin{array}{l}\text { - Lack of } \\
\text { education }\end{array}$ & 9 & $9 \%$ \\
\hline \multirow{4}{*}{$\begin{array}{l}\text { Women's } \\
\text { participation } \\
\text { level }\end{array}$} & \multirow{4}{*}{$\begin{array}{l}\text { Involvement of women } \\
\text { in the tourism industry } \\
\text { as managerial (Manager, } \\
\text { Supervisor and Craft) } \\
\text { and all others has been } \\
\text { categorized as non- } \\
\text { managerial participation. }\end{array}$} & - Managerial & 29 & $29 \%$ \\
\hline & & - Non- managerial & 71 & $71 \%$ \\
\hline & & & & \\
\hline & & Total & 100 & $100 \%$ \\
\hline
\end{tabular}

\subsection{Level of Women's Participation and Demographic Factors}

Women's participation in the tourism industry has been seen highly influenced by the age of the women. It is found that higher the age of women and lower the level of participation. It shows that younger women are more likely to participate in higher level posts as compared to the older age group in tourism industry. For example, the proportion of women holding managerial level dropped from 33\% among those who were 15-24 age 
groups to $24 \%$ among those who were $25-34$ years old. The percentage of women holding managerial level is $31 \%$ among those who were 35 and above years old (Table 3 ). The Chisquare test shows that age and the women's participation are not statistically significant. It means that age is not related with the women's participation even though younger women are more likely to be involved in managerial level positions.

Table 3: Respondent's Level of Participation in Tourism Industry

\begin{tabular}{|c|c|c|}
\hline \multirow{2}{*}{$\begin{array}{l}\text { Demographic factors } \\
\text { Age of the respondents }\end{array}$} & \multicolumn{2}{|c|}{ Level of women's participation } \\
\hline & $\begin{array}{c}\text { Managerial } \\
\text { (Manager, Supervisory or Craft) }\end{array}$ & $\begin{array}{l}\text { Non- managerial } \\
\text { (Operative ) }\end{array}$ \\
\hline $15-24$ & $32.6 \%$ & $67.4 \%$ \\
\hline $25-34$ & $24.4 \%$ & $75.6 \%$ \\
\hline 35 and above & $31.3 \%$ & $68.8 \%$ \\
\hline \multicolumn{3}{|c|}{ Marital status of the respondents * } \\
\hline Unmarried & $42.9 \%$ & $57.1 \%$ \\
\hline Married & $25.3 \%$ & $74.7 \%$ \\
\hline
\end{tabular}

Marital status of women has significant effect with their level of participation in tourism industry. Tourism industry sectors especially hotels prefer an unmarried women for the front positions that have to deal with the guests directly. Only not for this reason hotels prefer an unmarried women as an employee, they also want a woman who can give time even for the night shifts and early morning shifts which is a very difficult situation in practice for a married woman to manage. But for the higher positions, especially for the managerial positions, it is also seen that the tourism sectors prefer matured and experienced women who mostly are married. Similarly, for the backhouse positions and one time work hotels prefer married women also. The study shows that women with managerial level participation who were unmarried are about $43 \%$ and it was only $25 \%$ among the married women. Likewise, about $75 \%$ operative level women were married and $57 \%$ were unmarried. Hence, the test shows that unmarried women are more likely to have higher level of participation.

\subsection{Level of Women's Participation and Socioeconomic Factors}

Education has always been an important aspect for employment. It is a common trend and practice that the higher employment positions need higher educational level. 
Likewise we can say that higher the women's educational level, higher would be their level of participation in the tourism industry. This study also revealed that women with higher educational level have higher number of participation in the higher level positions. Similarly, lower educational level women have found more operative level participation. The study showed that the proportion of women holding managerial level positions rose from $14 \%$ among those having primary level of education to $95 \%$ among those having secondary and above level of education (Table 4). It showed that higher level of education is needed for holding better positions. The Chi-square test shows that educational level and the women's level of participation are statistically significant. It means that education is highly related with the women's skilled participation.

Most of the tourism industry sectors around Pokhara valley are operating as the family business. It is commonly found that the senior family members had initiated for the business and later other members of the family participated as the supporter and afterwards they run the business. If a family member is previously involved in a business sector either as an entrepreneur or as an employee, the other family members' access to the same business/sector becomes easier. In this study nearly half (41\%) of the respondents were found with prior family involvement in the tourism industry, and slightly more than half (59\%) have no prior family involvement in this sector. Out of 41 respondents with the prior family involvement in the tourism industry, about $44 \%$ have managerial level participation and $56 \%$ have operative level participation.

Table 4: Respondent's Level of Participation in Tourism Industry

\begin{tabular}{|c|c|c|}
\hline \multirow{2}{*}{ Socioeconomic factors } & \multicolumn{2}{|c|}{ Level of women's participation } \\
\hline & Managerial & Non- managerial \\
\hline Level of education**** & (Manager, Supervisory or Craft) & (Operative) \\
\hline \begin{tabular}{l|l} 
Primary \\
\end{tabular} & $13.5 \%$ & $86.5 \%$ \\
\hline Secondary & $13.8 \%$ & $86.2 \%$ \\
\hline \begin{tabular}{l|l} 
Above secondary \\
\end{tabular} & $94.7 \%$ & $5.3 \%$ \\
\hline \multicolumn{3}{|c|}{ Prior family involvement $* * *$} \\
\hline \begin{tabular}{l|l} 
& Involved \\
\end{tabular} & $43.9 \%$ & $56.1 \%$ \\
\hline Not Involved & $18.6 \%$ & $81.4 \%$ \\
\hline \multicolumn{3}{|c|}{ Involvement support factors } \\
\hline \begin{tabular}{l|l} 
& Friend's help
\end{tabular} & $8.1 \%$ & $90.9 \%$ \\
\hline Family help & $50.0 \%$ & $50.0 \%$ \\
\hline Self innovation & $25.0 \%$ & $75.0 \%$ \\
\hline Others'help & $50.0 \%$ & $50.0 \%$ \\
\hline Satisfaction from work & & \\
\hline
\end{tabular}




\begin{tabular}{|c|c|c|}
\hline Satisfied & $29.3 \%$ & $70.7 \%$ \\
\hline Not Satisfied & $0.0 \%$ & $100.0 \%$ \\
\hline \multicolumn{3}{|l|}{ Household headship* } \\
\hline \begin{tabular}{l|l} 
& Male
\end{tabular} & $28.3 \%$ & $71.7 \%$ \\
\hline Female & $37.5 \%$ & $62.5 \%$ \\
\hline \multicolumn{3}{|l|}{ Social barriers $* * *$} \\
\hline \begin{tabular}{l|l} 
Don't know \\
\end{tabular} & $50.0 \%$ & $50.0 \%$ \\
\hline Negative social thought & $19.2 \%$ & $80.8 \%$ \\
\hline Lack of wish & $100 \%$ & $0.0 \%$ \\
\hline Negative male attitude & $0.0 \%$ & $100 \%$ \\
\hline Unfavorable environment & $100 \%$ & $0.0 \%$ \\
\hline Home involvement & $28.6 \%$ & $71.4 \%$ \\
\hline Lack of awareness & $38.9 \%$ & $61.1 \%$ \\
\hline Lack of education & $22.2 \%$ & $77.8 \%$ \\
\hline Total & $29 \%$ & $71 \%$ \\
\hline
\end{tabular}

The study showed that the women with managerial level participation have more family support to involve in the tourism sector. One fourth (25\%) of them were participated in the managerial positions and same proportion in the supervisory positions with the family support. On the other side operative workers in this sector was found highest (91\%) with the support of friend. Thus, women who were involved in the tourism industry with the help of the family were found in the higher positions. It indicates that if a woman has family support to involve in the tourism sector she can deserve a higher position and/ or she can have higher positional participation. The KII also revealed the similar results. Hence the study showed that there is positive correlation between prior family involvement and women's managerial level participation in the tourism sector. The Chi-square test also shows the same result.

Work environment plays a very important role to a person's involvement in the outside employment. The work environment does not create an access to the employment but it encourages an employee for more output. If the work environment is favorable, an employee feels satisfaction and always tries for better outputs. Favorable work environment is necessary for the retention of an employee at an employment also. Work environment is not only internal, it is external too and both of these influence the employee's self motivation. Hence, a positive correlation can be seen between the favorable work environment and women's higher level participation in the tourism industry. In this study $30 \%$ of women were managers among those who were satisfied with the work environment and none of the dissatisfied women were managers. It showed that managerial level of involvement makes women more satisfied with their work environment comparing to those with operative 
level involvement.

Household head is found as the major decision maker within the family in Nepalese context and mostly male are dominating as the household head in our society. As a general practice, household head's decision becomes applicable in every aspects of a specific family's life. In many developing countries the same practice has been indicated by the foregoing literature review as well. In this study, $92 \%$ household headship is found dominated by male and only $8 \%$ has been found female headship. According to the respondents, female headship is not due to a general practice, but it is due to widow, separation and divorce type situations. It is found $28 \%$ of women were managers among male household head women whereas it is increased to $38 \%$ with female headed household. The result showed that female household headship is more supportive than male household headship to women's participation in the tourism industry.

Social barriers exist in the situation of strong cultural beliefs and superstitions that are deep routed in a society. Strong social barriers can be observed especially in the context of developing countries where rate of literacy is found low. The people of such society believe that these social barriers are in practice for their betterment and prosperity. In Nepalese context too, we can see many social barriers that are in existence and plays an important role to drive our social activities or society as a whole. For an example, if a woman wants to join an outside job, she has to face many problems. She can only get permission from the household head or family if they are well convinced about the job. The specific social barriers that have been faced by the respondents are shown in table 4 . Among those who thought negative social thought as a social barrier, $81 \%$ were lower level operative workers and all of the women were operative level workers who perceived that negative male attitude as the social barrier. The study result showed that negative social thought, negative male attitude and the lack of awareness about women's participation in the tourism industry are the major social barriers.

\section{Conclusions and Recommendations}

Women's managerial level participation in the tourism industry specifically in the hospitality industry has found very low (29\%). However, their participation is seen in an increasing trend with very low pace. In conclusion the study revealed that demographic factors have no strong influence on women's level of participation in this sector. However, socioeconomic factors have found high influence on women's participation. In this regard education has seen a major influencing factor. The result showed that higher the education 
level more the women's level of participation. At the same time other socioeconomic factors have also been influencing factors for women's level participation. The KII also explores the similar findings.

Based on the findings it is suggested to future researchers to include more demographic and socio-economic variables such as: family structure, family size, parity, and household economic status as independent variable to identify the more reliable results in this regard. Furthermore women should be given priority to participate in the higher level positions because skilled participation is required not an unskilled one. However, for enhancing women's participation in higher level posts; information, education and communication programs should be launched by the government agencies and other concerned stakeholders.

\section{REFERENCES}

Anand, M.M., \& Bajracharya, P. (1985). Strategies for the development tourism in Nepal. Gurans. Delhi: Nepalese Student Association.

Bhatia, A.K. (1994). International tourism. New Delhi: Sterling Publishers Private Limited.

Daddi, S. (2002). Fem-treks: Practicing feminist tourism in Nepal. Unpublished master's dissertation. Department of Anthropology, Barnard Collage, USA.

Jackson, I. (1995). An introduction to tourism. Melbourne: Hospitality Press.

Keefe, J., \& Wheat, S. (1998). Tourism and human rights. London: Tourism Concern.

National Planning Commission, (NPC) (2003). Tenth plan: Poverty reduction strategy paper. Kathmandu: NPC.

Nepal Rastra Bank (NRB) (1989). Economic survey, 1988/89. Kathamandu: NRB

Nepal Tourism Board (NTB) (2000). NTB in focus 1999-2001, [Special issue on $3^{\text {rd }}$ Anniversary]. Kathmandu: NTB

Oli, G.S., \& Chhetri, B.B. (2002). A book on hotel management. Kathmandu: Durga Books.

Shrestha, H. P. (2000). Tourism in Nepal: Marketing challenges. New Delhi: Niraula Publications.

Sijtsma, W. (2001). Tourism training development for women's empowerment: An amendatory methodology.

Unpublished master's dissertation. DTLS, Netherlands Institute of Tourism and Transport Studies.

Tourism Office. (2005). Information brochure 2005, [Brochure]. Pokhara: Author 